by 15 per cent to 3,223 , while the number of continuous classes rose to 1,369 , an increase of 35 per cent.

Topics of current interest were responsible for much of the increase, while the increase in non-vocational science and psychology (classified separately) was very considerable. Handicrafts again proved popular and increased in number, but the shortage of materials has hindered the formation of classes in a number of crafts.

The growing volume of work undertaken by the regional committec $\mathrm{s}$ is a tribute not only to all the individuals who take part in the work but also to the Service authorities for their wisdom in encouraging educational activities am ng serving men and women.

\section{PROPOSALS FOR NEW BASIC PHYSICAL POSTULATES}

TN a series of papers published in 1942, some in the 1 Manual of Myiology, Dr. H. T. Townsend, of S. Paulo, Brazil, puts forward a revolutionary set of new physical theories. While there does not appear to be adequate evidence for the views put forward in the papers under notice, the following are principal postulates, mainly in the author's own words :

Centrifugal force is inherent in all cosmogen (mass + motion) and is the most basic cosmic force. Gravity is an equally basic cosmic force. Hence the two are one and the same force. Gravity is the complement of bound centrifugal force. It is unbound centrifugal force. Centrifugal force makes up all cosmogen by its interaction with the actinionic medium. Spinning actinions spinning round a vortex centre are the basis and the electron formed from them spins inherently. Spinning atoms are formed from spinning electrons and spinning molecules from spinning atoms. Centrifugal force centres vary from innumerable microfield centres (vortices in the medium) to the single great cosmic field centre, and each maintains its individual electro-magnetodynamic (commonly called magnetic) field. The repulsions between these fields constitute the force of gravity. Electromagnetic radiation is micro-centrifugal fields in wave formation travelling at top speed in the transmitting (actionic) medium.

The number of atomic weight units in the elec. tronic unit is 546, which thus becomes the basic physical constant. All the atomic weights of the chemical elements are multiples of 546. The actinion carries the force quantum of $12 \times 10^{-30} \mathrm{dyne}$, the equivalent of the motion of 546 actinions constituting a photon. A photon is pure energy acting on the mass of the transmitting actionic medium. The ultimate force quantum is the dynamion, which on coming in contact with an ultimate mass particle or akinesion at once imparts to it an ultimate energy quantum or kinesion, resulting in an actinion. A photon is 546 kinesions, or the result of 546 liberated dynamions imparting 546 motion units to as many actinions.

Applying the 546-multiple key to the light-velocity problem, it is found that the only number within the limited range of Michelson's (1927) experimental results that is a multiple of the square of 546 is 29979737424, which is also within the Henning and Jaeger corrected range of Rosa and Dorsey's (1907) measurements of the electrostatic unit to the electromagnetic unit ratio in our terms of light velocity. It is Michelson's lower to mean record plus the possible retardation by his mirrors.

\section{FORTHCOMING EVENTS}

\author{
Saturday, September II
}

British Federation of Busingss and Professional Women (at the Royal Institution, 21 Albemarle Street, Piccadilly, London, W 1) at 3 p.m.-Dr. Margaret Mead: "Science, Women and the Problem of Power".

\section{Saturday, September 18}

BRITISH RHEOLOGIST'S CLUB (at Loughborough College, Loughborough), at 10 a.m.-Discussion on "Rheology in the Hosiery, Leather, Shoe and Allied Trades".

ASSOCIATION FOR SCIENTIFIC PHOTOGRAPHY (at the Middlesex Hospital, London, W.1), at 2.30 p.m.-Discussion on "Clinical Photography".

Saturday, September 18-Sunday, September 19

Assoctation OF SPECIAL LIBRARIES aND INFORMation BUREAUX (at the Royal Society, Burlington House, Piccadilly, London, W.1).Eighteenth ASLIB Conference.

Saturday, September 18

10.30 a.m.-Annual General Meeting.

11.30 a.m.-.-Prof. J. D. Bernal, F.R.S.: "Positive Information

2.0 p.m.-Symposium on "The International Rehabilitation of Special Library Services".

Sunday, September 19

10.30 a.m.-Mr. F. C. Francis: "The British Museum as a Special Library".

11.45 a.m.-Major Irving Newman : "The Organisation of American Photographic Information Services in Great Britain".

2.30 p.m.- Symposium on "The Co-ordination of Abstracting".

5.0 p.m.- "ASLIB : What it is Doing and What it Hopes to Do",

\section{APPOINTMENTS VACANT}

APPLICATIONS are invited for the following appointments on or before the dates mentioned

assistant Master to teach Engineering DRAwing in the Mid dlesbrough Technical School for Boys-The Director of Education, Education Offices, Middlesbrough (September 18)

HeAD OF THE DEPaRTMENT OF MATHeMatics-The Principal, Heriot Watt College, Edinburgh (September 20).

heads of the Departments of Physiology, Medicine, avi SURGEHY-The Bursar, Royal Veterinary College and Hospital, at The University, Reading (October 1 )

ChaIR of NAval ARchitecture-The Acting Secretary of University Court, The University, Glasgow (October 4).

DIRECTOR OF ROBERT GORDON'S TECHNICAI COLLEGE-The Secre tary, Robert Gordon's 'Technical College, Aberdeen (October 16).

CHIEF CERAMIC RESEARCH CHEMIST-The Ministry of Labour and National Service, Central (Technical and Scientific) Register Labour and House, Kingsway, London, W.C.2 (quoting Reference No. O.N.F. $1457 \mathrm{X})$.

\section{REPORTS and other PUBLICATIONS}

\author{
(not included in the monthly Books Supplement)
}

\section{Great Britain and Ireland}

London School of Hygiene and Tropical Medicine (University of London) incorporating the Ross Institute. Report of a Meeting of the Ross Institute Industrial Advisory Committee on Thursday 27th May 1943. Pp. 24. (London: London School of Hygiene and Tropical Medicine.)
[128 Imperial Agricultural Bureaux. Joint Publication No. 5 : The Production of Seed of Root Crops and Vegetables. Pp. 96. (East Malling: Imperial Bureau of Horticulture and Plantation Crops Aberystwyth: Imperial Bureau of Pastures and Forage Crops Cambridge: Imperial Bureau of Plant Breeding and Genetics.) Institute of Welding. Twentieth Annual Report of the Council, Accounts and Balance Sheet to 31 December 1942. Pp. 20. (London Accounts and Batute of Welding.)
[178 Otto Jespersen : his Work for an International Auxiliary Language. By H. Jacob. Pp. 32. (Loughton: International Language (Ido) Society of Great Britain.) $1 s$.

\section{Other Countries}

Proceedings of the Academy of Natural Sciences of Philadelphia. Vol. 93, 1941. Pp. iii +336. (Philadelphia, Pa. : Academy of Natural Sciences.) 7.50 dollars. $[128$ Fifty-eighth Annual Report of the Bureau of American Ethnology to the Secretary of the Smithsonian Institution, 1940-1941. Pp. 13. (Washington, D.C. : Government Printing Office.) [128 Smithsonian Institution: Bureau of American Ethnology. Bulletin 129: An Archaeological Survey of Pickwick Basin in the adjacent portions of the States of Alabama, Mississippi and Tennessee. By William S. Webb and David $\mathbf{L}$. DeJarnette; with Additions by Walcer B. Jones, J. P. E. Morrison, Marshall T. Newman and Charles E. Snow and William G. Haag. Pp. xxii $+536+316$ plates. (Washington, 